\title{
Survey about the knowledge of farmers in Wielkopolska region of integrated pest management
}

\author{
Wiedza producentów rolnych z regionu Wielkopolski \\ na temat integrowanej ochrony roślin w badaniach ankietowych
}

\author{
Magdalena Jakubowska ${ }^{1}{ }^{*}$, Andrzej Obst $^{2}$, Anna Tratwal $^{1}$, Kamila Roik $^{1}$, Beata Wielkopolan $^{1}$
}

\section{Summary}

The aim of research was to evaluate the knowledge of agricultural producers about integrated pest management, in the region of Wielkopolska. Particular attention was paid to determine the expectations of advisory service, necessity of training and other forms of dissemination of knowledge. The surveys were conducted in 2014 and 2015 in the region of Wielkopolska. The total of 243 agricultural producers filled the questionnaire that contained 26 questions in 2014, and 140 in 2015. Both women and men at the age of 24-70 participated in this research. Based on the obtained responses we tried to answer the question if the knowledge of agricultural producers about integrated pest management depends on age, education or farm area. The statistical analysis indicates that education, and place of residence (district) have a significant impact on the awareness of agricultural producers about integrated pest management. On the other hand the age and farm area had not impact on knowledge of agricultural producers.

Key words: integrated pest management; knowledge; awareness; farmer

\section{Streszczenie}

Celem badania była diagnoza świadomości producentów rolnych z zakresu integrowanej ochrony roślin z regionu Wielkopolski. Szczególną uwagę zwrócono na określenie oczekiwań w zakresie tematyki doradztwa, potrzeb szkoleniowych i innych form poszerzenia wiedzy. Badanie ankietowe zostało przeprowadzone na terenie województwa wielkopolskiego w latach $2014-2015$. Zankietowano 243 producentów rolnych w roku 2014, a w roku 2015 - 140. Respondentami byli mężczyźni i kobiety w wieku 24-70 lat. Na podstawie 26 pytań ankietowych próbowano stwierdzić, czy posiadana wiedza na temat zagadnień związanych z integrowaną ochroną uzależniona jest od wieku, wykształcenia lub powierzchni prowadzonego gospodarstwa rolnego. Na podstawie analizy statystycznej wykazano istotną zależność wyrażania przez rolników opinii na temat ich wiedzy z zakresu omawianych zagadnień z ich wykształceniem, przy czym wiek nie odgrywał tu istotnej roli. Ponadto, stwierdzono istotne różnice w świadomości rolników w zależności od powiatów, w których zamieszkiwali. Wielkość gospodarstwa w żaden sposób nie wpływała na posiadaną wiedzę wśród ankietowanych.

Słowa kluczowe: integrowana ochrona roślin; wiedza; świadomość; producent rolny

\footnotetext{
${ }^{1}$ Instytut Ochrony Roślin - Państwowy Instytut Badawczy

Zakład Metod Prognozowania Agrofagów i Ekonomiki Ochrony Roślin

Władysława Węgorka 20, 60-318 Poznań

${ }^{2}$ Wielkopolski Ośrodek Doradztwa Rolniczego

Sieradzka 29, 60-163 Poznań

*corresponding author: m.jakubowska@iorpib.poznan.pl
} 


\section{Wstęp / Introduction}

Znaczenie środowiska w produkcji rolniczej i konieczność jego ochrony wynika między innymi z faktu postępującej intensyfikacji produkcji, zmian w legislacji ochrony środowiska oraz zmian $\mathrm{w}$ asortymencie i prawie dotyczącym stosowania środków ochrony roślin. Z punktu widzenia oddziaływania na środowisko ważna jest również ochrona przed agrofagami (chorobami, szkodnikami, chwastami, itp.).

Obecnie priorytetem w wymaganiach jakie stawia Unia Europejska (UE) przed wszystkimi producentami i konsumentami jest przede wszystkim zdrowie publiczne i wysoka jakość żywności oraz ochrona środowiska. Realizację tych celów zapewnia między innymi obowiązek stosowania zasad integrowanej ochrony roślin przez wszystkich profesjonalnych użytkowników środków ochrony roślin w Polsce oraz pozostałych państwach członkowskich UE (obowiązuje od dnia 1 stycznia 2014 r.). Według Dyrektywy Parlamentu Europejskiego i Rady 2009/128/WE z dnia 21 października 2009 r. oraz Rozporządzenia (WE) nr 1107/2009, stosowanie integrowanej ochrony roślin polega na wykorzystaniu wszelkich dostępnych metod ochrony roślin przed organizmami szkodliwymi, w szczególności metod niechemicznych, minimalizujących ryzyko zagrożenia dla zdrowia ludzi, zwierząt oraz dla środowiska. Ogólne zasady integrowanej ochrony roślin obejmują między innymi: przedkładanie metod biologicznych i innych niechemicznych nad metody chemiczne, celowe stosowanie pestycydów, ograniczanie stosowania pestycydów do niezbędnego minimum, stosowanie strategii przeciwdziałających rozwojowi odporności organizmów na dany preparat i prowadzenie zapisów o zastosowanych pestycydach (Czernyszewicz i wsp. 2015).

W produkcji roślinnej nie można wykluczyć stosowania chemicznych środków ochrony roślin, ale trzeba zawsze mieć na uwadze, że muszą być one używane w sposób odpowiedzialny, korzystny ekonomicznie i uwzględniający aspekt społeczny. Mając na uwadze wymagania integrowanej ochrony roślin, ochrony środowiska i presję konsumentów, dużego znaczenia nabierają działania zmierzające do ograniczenia liczby zabiegów chemicznych zwalczających agrofagi, przy jednoczesnym zachowaniu ich maksymalnej skuteczności (Tratwal i wsp. 2014). Przy wyznaczeniu optymalnego terminu zwalczania agrofagów należy przede wszystkim kierować się prawidłowo prowadzonym monitoringiem szkodnika (Walczak 1999; Walczak i wsp. 2010). Szczegółowa lustracja pola polega na systematycznych obserwacjach organizmów szkodliwych w celu określenia nasilenia ich występowania, liczebności czy procentowego opanowania roślin. Prowadzony monitoring jest podstawą do podjęcia decyzji o wykonaniu zabiegu chemicznego w przypadku przekroczenia progu ekonomicznej szkodliwości (Matyjaszczyk i wsp. 2010; Golinowska i wsp. 2014; Kruszyński i wsp. 2015). Dobra praktyka ochrony roślin, jak i wymagania integrowanej produkcji i ochrony roślin przyczyniają się do wykonania zabiegów w najbardziej optymalnym terminie przy uwzględnieniu progów szkodliwości.

Niski poziom wykształcenia jest poważną barierą $\mathrm{w}$ upowszechnianiu poprawnych praktyk w produkcji rol- niczej. Wymogi wynikające z członkowska w UE powodują, że rolnicy poszukują informacji lub fachowej wiedzy w ośrodkach doradztwa rolniczego (Kiełbasa i Krysztoforski 2009).

Wysoko rozwinięta świadomość dotycząca zagadnień związanych z integrowaną ochroną roślin oraz pozytywne i przyjazne dla środowiska postawy i działania, wymagają dobrze zaplanowanego i konsekwentnie realizowanego kształcenia. Jedną $\mathrm{z}$ jego form jest prawidłowo prowadzone doradztwo rolnicze $\mathrm{z}$ wysoko wykwalifikowaną kadrą doradców.

Celem badania była diagnoza świadomości producentów rolnych $\mathrm{z}$ regionu Wielkopolski na temat ogólnego stanu wiedzy dotyczącej zagadnień związanych z integrowaną ochroną roślin.

\section{Materiały i metody / Materials and methods}

Postawiony cel pracy zrealizowano na podstawie badań ankietowych przeprowadzonych w pierwszym i drugim kwartale roku. Badaniem ankietowym objęto rolników z terenu województwa wielkopolskiego, którzy byli uczestnikami szkoleń przeprowadzonych przez Wielkopolski Ośrodek Doradztwa Rolniczego w Poznaniu. W latach 2014-2015 na ankiety odpowiedziało łącznie 383 producentów rolnych (w tym w roku $2014-243$, a w roku 2015 - 140) reprezentujących razem 30 powiatów. Respondentami byli mężczyźni i kobiety w wieku 24-70 lat. Ankietowani odpowiadali na 26 pytań zamkniętych, z możliwością wielokrotnego wyboru. Uczestnikami badania byli właściciele gospodarstw rolnych, którzy brali udział w szkoleniach, kursach zainicjowanych w ośrodkach doradztwa rolniczego, dobrani według wskazanych kryteriów (tj. płci, wieku, wykształcenia, powierzchni użytkowanego gospodarstwa oraz dostępu do internetu). Badania ankietowe przeprowadzono w gospodarstwach o różnych kierunkach produkcji i powierzchni co najmniej lub równej 1 ha $\mathrm{UR}$, w których działalność rolnicza jest głównym źródłem dochodu, pominięto gospodarstwa specjalistyczne. Zestawienia uzyskanych danych dokonano w formie graficznej oraz tabelaryczno-opisowej. Uzyskane dane źródłowe pogrupowano według cech i liczebności odpowiedzi, obliczono średnie i wskaźniki struktury dla poszczególnych cech oraz poddano je analizie porównawczej i statystycznej. Aby wyznaczyć poziom wiedzy odnośnie znajomości zagadnień związanych z integrowaną ochroną roślin wybrano odpowiednie pytania $\mathrm{z}$ ankiety i wariantom odpowiedzi świadczącym o wyższym stopniu wiedzy przypisano większe wartości liczbowe. Ogólny stan wiedzy został określony jako wartość sumaryczna odpowiedzi na poszczególne pytania. Zróżnicowanie poziomu wiedzy ze względu na dane metryczkowe zostało zbadane za pomocą testu jednoczynnikowej analizy wariancji ANOVA przy przyjętym poziomie istotności $\alpha=$ 0,05 . W przypadku, gdy test ANOVA dawał pozytywny rezultat zastosowano test post-hoc NIR (Najmniejsze Istotne Różnice) do zbadania między którymi grupami zachodzą statystycznie istotne różnice.

Do obliczeń statystycznych wykorzystano pakiet statystyczny STATISTICA v. 12.0. 


\section{Wyniki i dyskusja / Results and discussion}

Przemiany społeczno-polityczne końca 20 . wieku oraz przystąpienie Polski do UE spowodowały ogromne zmiany $\mathrm{w}$ rolnictwie. Zmiany te spowodowały zwiększenie zapotrzebowania na nowoczesną wiedzę. W poniższym artykule przedstawiono najważniejsze wnioski z wyników badania, dotyczące ważnych kwestii związanych z oceną świadomości producentów rolnych $\mathrm{w}$ zakresie wiedzy na temat ogólnych zagadnień związanych $\mathrm{z}$ integrowaną ochroną roślin.

Po roku obowiązywania Dyrektywy UE na pytanie dotyczące terminu ,integrowana ochrona roślin”, większość z producentów rolnych $(97,8 \%)$ odpowiada że, jest świadoma powszechnego i obowiązkowego jej stosowania $\mathrm{w}$ prowadzeniu gospodarstwa rolnego. $\mathrm{Z}$ grupy tej około $37,8 \%$ rolników udzieliło odpowiedzi, że pierwszy raz o definicji ,integrowana ochrona roślin” usłyszeli w momencie wejścia w życie Dyrektywy UE, wskazując datę 1 stycznia 2014 roku jako datę wejścia w życie tego obowiązku w Polsce.

Ankietowani pytani w formularzu o znajomość metod ochrony upraw przed agrofagami w $43,6 \%$ odpowiadali, że są im znane różne metody, np. biologiczna, mechaniczna, chemiczna, hodowlana, itd.; 35,5\% rolników wskazywała na trzy rodzaje metod: chemiczna, mechaniczna i hodowlana; $14,7 \%$ odpowiadało, że zna i korzysta tylko $\mathrm{z}$ chemicznej ochrony upraw przed zagrożeniami ze strony chorób, szkodników czy chwastów. Tylko 6,0\% odpowiadało, że nie korzysta $\mathrm{z}$ żadnych form ochrony. W kwestii stosowania chemicznych środków ochrony roślin w gospodarstwach, zdecydowana większość rolników wskazywała niezbędność ich stosowania. Pytani o pozytywne i negatywne skutki stosowania chemicznych preparatów, wśród najbardziej istotnych zalet wymieniają: wysoką ich skuteczność, szybkie działanie, zwiększenie plonowania oraz niski nakład pracy. Natomiast jako negatywne skutki ich zastosowania wymieniają przede wszystkim: wysoką ich cenę, szkodliwość dla zdrowia ludzi i zwierząt, powstawanie odporności chorób, szkodników i chwastów wynikające $\mathrm{z}$ ich nadmiernego stosowania oraz degradację środowiska.

Znajomość progu ekonomicznej szkodliwości, który wiąże się $\mathrm{z}$ integrowaną ochroną roślin, a polega na określaniu liczebności szkodnika, nasilenia choroby czy liczby chwastów, przy której wartość spodziewanej utraty plonu przewyższa koszt wykonania zabiegu ochronnego, zadeklarowało $25,7 \%$ ankietowanych. Kolejna duża grupa rolników $(45,7 \%)$ potwierdziła, że stosuje pestycydy po stwierdzeniu śladów żerowania szkodnika czy wystąpienia choroby, nie przestrzegając progu szkodliwości, zaś $28,6 \%$ badanych rolników przyznało się do stosowania chemicznych środków ochrony bez potrzeby ustalenia progu szkodliwości. Prawdopodobnie wynikało to $\mathrm{z}$ nieumiejętności prawidłowego zdefiniowania progu szkodliwości.

$\mathrm{W}$ badanej grupie wielkopolskich producentów rolnych dominowali rolnicy, głównie mężczyźni $(89,2 \%)$, którzy reprezentowali przedział wiekowy 45-60. rok życia (41,7\%). Młodzi rolnicy, czyli ci, którzy nie przekroczyli 45. roku życia stanowili $28,9 \%$. Rolnicy ankietowani do 24. roku życia stanowili 4,2\%, w przedziale wiekowym od
25-34. roku życia - 20,8\% i powyżej 60. roku życia $4,4 \%$. Większość ankietowanych rolników gospodarowała na areale od 20 do 50 ha - 36,1\% (producenci rolni i rolnicy indywidualni), następnie od 10 do 20 ha $-32,3 \%$ (rolnicy indywidualni). Rolnicy gospodarujący na powierzchni powyżej 50 ha stanowili około $22 \%$. Wśród ankietowanych dominowały dwa rodzaje produkcji: roślinna i zwierzęca $(63,6 \%)$, w tym produkcja roślinna stanowiła około $20,0 \%$, gdzie dominującymi uprawami były zboża $(46,9 \% \quad$ w odpowiedziach ankietowanych), kukurydza $(22,6 \%)$, rzepak $(13,2 \%)$ i okopowe $(13,1 \%)$. Pod względem wykształcenia dominowały osoby legitymujące się dyplomem ukończenia szkoły średniej (45,3\%). Wykształcenie zasadnicze zawodowe zadeklarowało $37,2 \%$ rolników, wyższe $15,0 \%$, zaś absolwenci szkół podstawowych i gimnazjalnych stanowili w badanej próbie 2,2\%. Na podstawie postawionej hipotezy: jak poziom wykształcenia oraz wiek badanych wpływa na stan wiedzy rolników na temat integrowanej ochrony roślin w świetle zebranych odpowiedzi potwierdza się wyraźnie, że wykształcenie zwiększa świadomość rolników o potrzebie wdrażania systemów uprawy zmniejszających zagrożenie człowieka i środowiska naturalnego. Rolnicy posiadający średnie i wyższe wykształcenie (82,5\% ankietowanych) znacznie częściej niż pozostali odpowiadali ze zrozumieniem na wskazane pytania w ankiecie.

Osoby młode, częściej niż starsze wskazywały, że przedsiębiorstwo rolne powinno być prowadzone zgodnie z wytycznymi, dla zabezpieczenia zdrowej żywności i ograniczenia kosztów przez zmniejszenie liczby zabiegów chemicznych przeciw agrofagom, szkodliwych dla środowiska (tab. 1, rys. 1). Podobnie, jak w badaniach przeprowadzonych przez Czernyszewicz i Pawlaka (2012), z przeanalizowanych ankiet wynika, że wraz z wiekiem, stosowanie systemów zmniejszających ryzyko zagrożeń dla ludzi i środowiska malało. Przy czym rolnicy w wieku powyżej 60. roku życia $\mathrm{z}$ większą świadomością odpowiadali na zadawane pytania dotyczące zagadnień związanych $\mathrm{z}$ integrowaną ochroną roślin, prawdopodobnie ze względu na swoje długoletnie doświadczenie w prowadzeniu gospodarstwa rolnego (rys. 1).

$\mathrm{Na}$ podstawie analizy statystycznej wykazano istotną zależność wyrażania przez rolników opinii na temat ich wiedzy $\mathrm{z}$ zakresu omawianych zagadnień a ich wykształceniem, przy czym wiek nie odgrywał tu istotnej roli (tab. 1, rys. 2). Stwierdzono istotne różnice między grupami rolników posiadających wykształcenie podstawowe i zawodowe w stosunku do rolników legitymujących się wykształceniem na poziomie średnim i wyższym, przy czym dwie ostatnie grupy nie różniły się istotnie (rys. 2).

$\mathrm{W}$ odpowiedziach ankietowanych wykazano istotna zależność wyrażania przez rolników opinii na temat ich wiedzy z zakresu omawianych zagadnień a powierzchnią uprawianego gospodarstwa, przy czym rolnicy gospodarujący większym areałem (powyżej 100 ha) wykazywali się większą znajomością metod i zagadnień związanych $\mathrm{z}$ integrowaną ochroną roślin (tab. 1, rys. 3).

W przypadku korzystania z serwisów informacyjnych umieszczanych na stronach internetowych związanych z poszukiwaniem wiedzy na temat integrowanej ochrony, $42,1 \%$ ankietowanych odpowiedziało, że korzysta w celu 
sprawdzenia warunków meteorologicznych, dostępnych metod i programów oraz zarejestrowanych preparatów chemicznych. Tylko 22,7\% ankietowanych opowiedziało się, że korzysta regularnie. Niestety, 32,0\% badanych odpowiedziało w sposób negatywny, tzn. że nie ma potrzeby poszerzania wiedzy na ten temat za pomocą serwisów informacyjnych umieszczanych w internecie. Analiza pozyskanych informacji w badaniach Czekaj (2013)

Tabela 1. Wartości średnie i odchylenia standardowe poziomu wiedzy rolników sklasyfikowane dla poszczególnych czynników różnicujących

Table 1. The mean values and standard deviation values of knowledge of farmers classified for specific differentiating factors

\begin{tabular}{|c|c|c|c|}
\hline \multicolumn{3}{|c|}{$\begin{array}{l}\text { Poziom wiedzy na temat integrowanej ochrony roślin } \\
\text { Knowledge level about the integrated pest management }\end{array}$} & \multirow{2}{*}{$\begin{array}{l}\text { ANOVA } \\
\mathrm{p}\end{array}$} \\
\hline $\begin{array}{l}\text { Czynnik/warianty } \\
\text { Factor/variants }\end{array}$ & $\begin{array}{c}\text { średnia } \\
\text { mean }\end{array}$ & $\begin{array}{l}\text { odchylenie standardowe } \\
\text { standard deviation }\end{array}$ & \\
\hline \multicolumn{4}{|c|}{ Płeć - Gender } \\
\hline Mężczyzna - Male & 24,32 & 5,34 & \multirow{2}{*}{0,54992} \\
\hline Kobieta - Female & 23,81 & 4,23 & \\
\hline \multicolumn{4}{|c|}{ Wiek - Age } \\
\hline Do 24 lat - Up to 24 years & 25,14 & 5,21 & \multirow{5}{*}{0,03202} \\
\hline $25-34$ lat $-25-34$ years & 25,66 & 5,48 & \\
\hline $35-44$ lat $-35-44$ years & 23,90 & 4,99 & \\
\hline $45-60$ lat $-45-60$ years & 23,57 & 4,77 & \\
\hline$>60$ lat - Above 60 years & 24,58 & 8,70 & \\
\hline \multicolumn{4}{|c|}{ Wykształcenie - Education } \\
\hline Podstawowe - Primary & 20,60 & 2,07 & \multirow{4}{*}{0,00001} \\
\hline Zawodowe - Professional education & 21,63 & 5,24 & \\
\hline Średnie - Secondary & 25,11 & 4,27 & \\
\hline Wyższe - Higher & 28,38 & 4,71 & \\
\hline \multicolumn{4}{|c|}{ Powierzchnia - Area } \\
\hline $0-15$ ha $-0-15$ hectares & 21,50 & 6,07 & \multirow{4}{*}{0,00073} \\
\hline $15-50$ ha $-15-50$ hectares & 23,57 & 5,48 & \\
\hline $50-100$ ha $-50-100$ hectares & 22,99 & 5,54 & \\
\hline$>100$ ha - Above 100 hectares & 25,25 & 4,73 & \\
\hline \multicolumn{4}{|c|}{ Dostęp do internetu - Internet access } \\
\hline Tak-Yes & 24,75 & 5,10 & \multirow{2}{*}{0,00001} \\
\hline Nie - No & 20,36 & 4,64 & \\
\hline
\end{tabular}

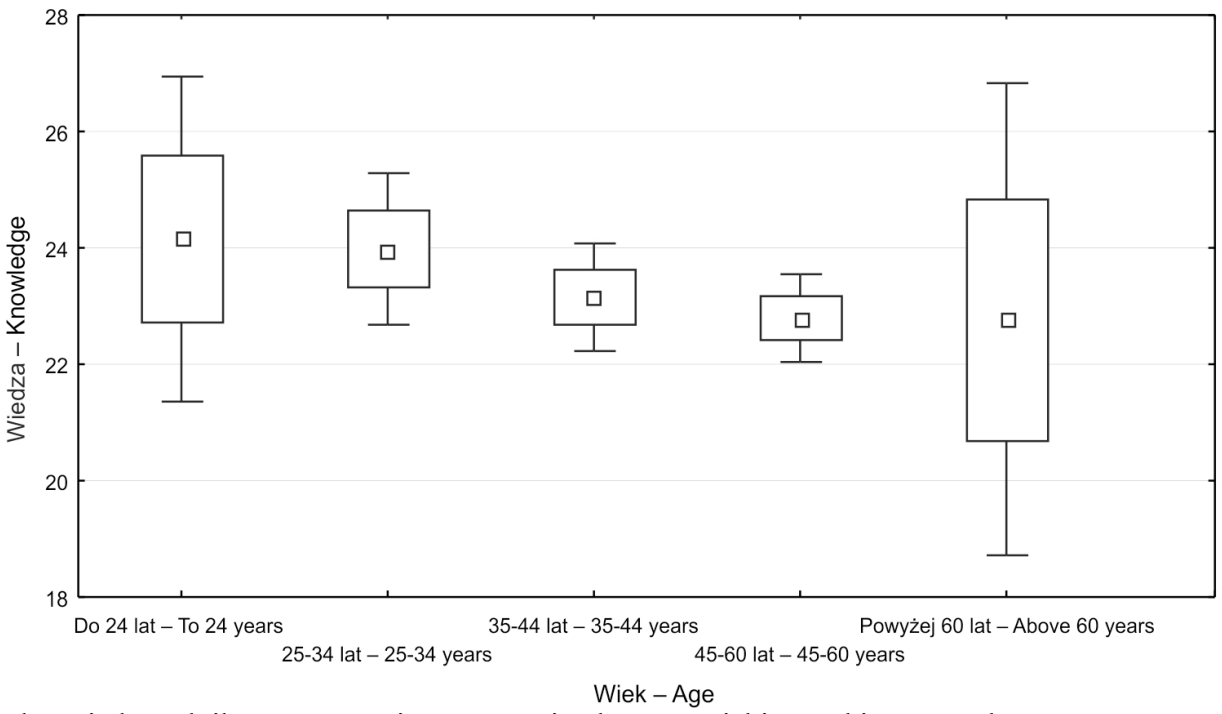

Rys. 1. Zależność między wiedzą rolników na temat integrowanej ochrony a wiekiem ankietowanych

Fig. 1. Box-and whisker plot of variation of age and knowledge of farmers of integrated pest management (IPM) 


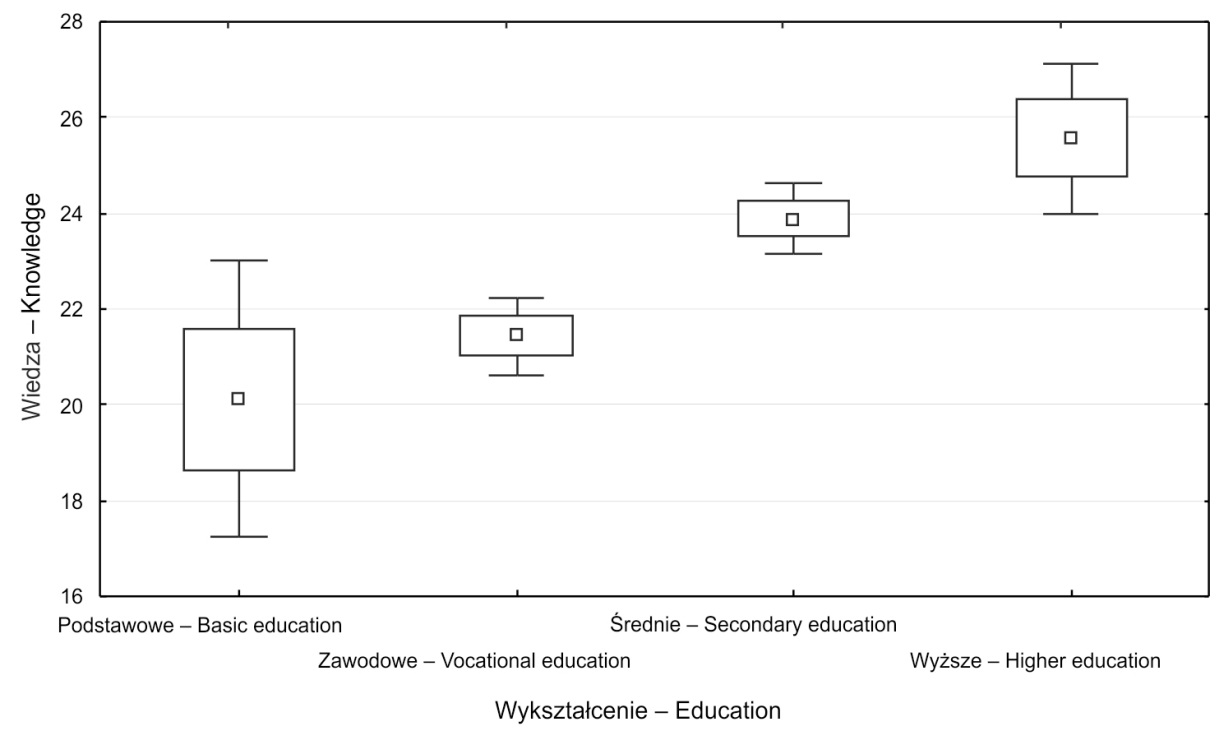

Rys. 2. Zależność między wiedzą rolników na temat integrowanej ochrony a posiadanym wykształceniem Fig. 2. Box-and whisker plot of variation of education and knowledge of farmers of IPM

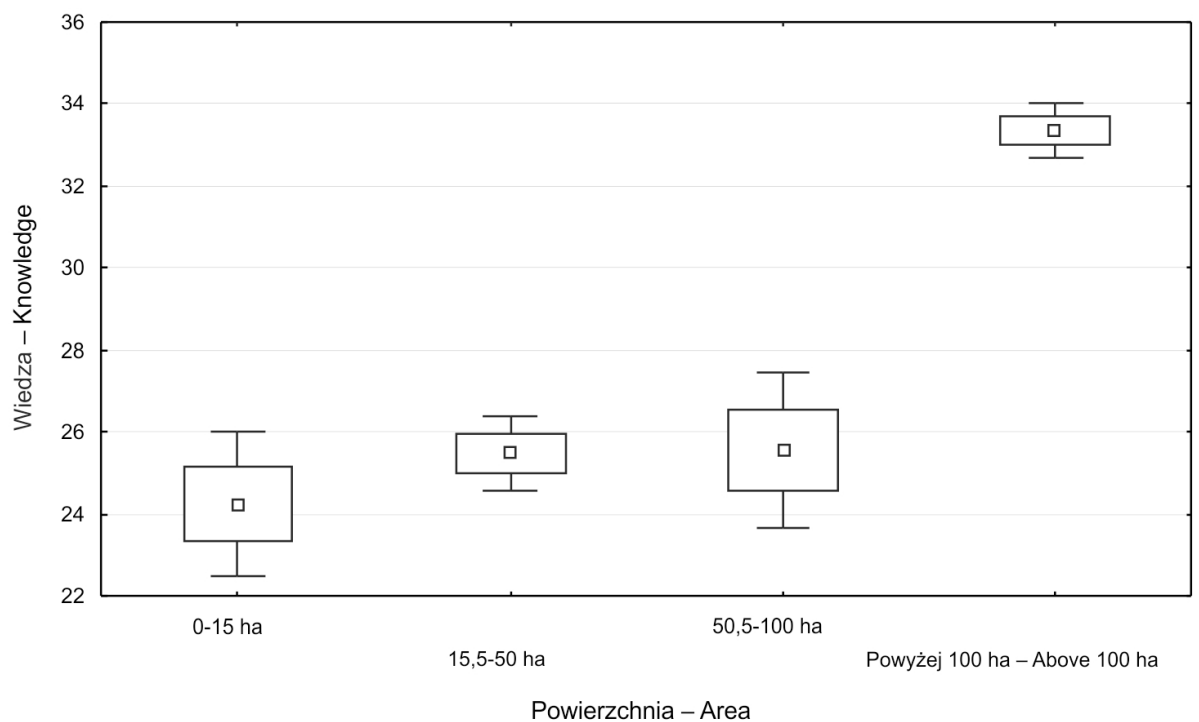

Rys. 3. Zależność między wiedzą rolników na temat integrowanej ochrony a powierzchnią gospodarstwa Fig. 3. Box-and whisker plot of variation of surface area and knowledge of farmers of IPM

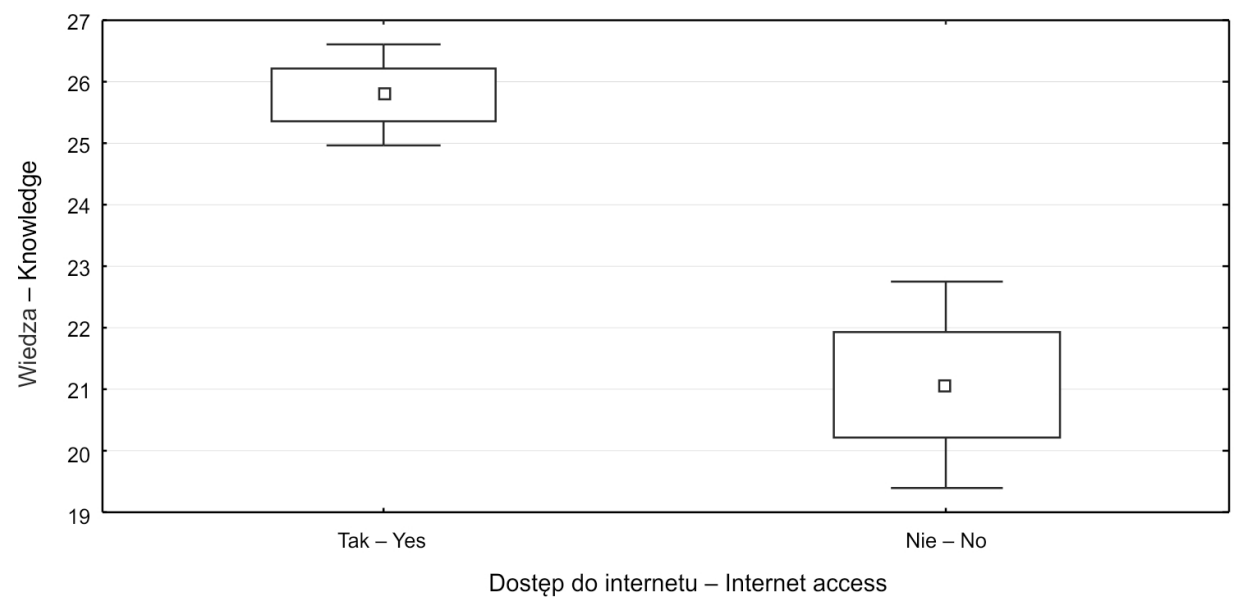

Rys. 4. Zależność między wiedzą rolników na temat integrowanej ochrony a dostępem do internetu Fig. 4. Box-and whisker plot of variation of internet access and knowledge of farmers of IPM 
pozwoliła stwierdzić, że wciąż znaczny odsetek rolników nie posiada komputerów w gospodarstwach rolnych (województwo małopolskie) (18,7\%), a w grupie mających taki sprzęt $12,3 \%$ nie potrafi go obsługiwać. Autorka w swoich badaniach przytacza, że rolnicy wykorzystują najczęściej komputery stacjonarne, jak i przenośne. Według autorki ankietowani dobrze oceniają przydatność sprzętu - niemal $60,0 \%$ wskazało, że jest on $\mathrm{z}$ ich punktu widzenia przydatny, bądź bardzo przydatny w gospodarstwie rolnym. Inni autorzy, jak Marks i wsp. (2012) czy Bisaga (2014) jednym $z$ głównych powodów niedostatecznego wykorzystania komputerów w prowadzeniu gospodarstwa rolnego wskazują brak dostępu do technologii informacyjno-telekomunikacyjnych oraz czynniki ograniczające ten dostęp, np. brak lub wadliwe połączenia sieciowe w wybranych miejscowościach. Na podstawie wyników przeprowadzonego przez zespół badania wynika, że ponad 32,0\% ankietowanych nie korzystało lub nie korzysta $\mathrm{z}$ komputera, internetu i nie chce szkoleń e-lerningowych. Przyczyny tego zjawiska można upatrywać w braku dostępu do sieci internetowych lub braku znajomości obsługi komputera. $\mathrm{Na}$ podstawie analizy statystycznej wykazano istotny wpływ korzystania z usług internetu na poziom wiedzy rolników (tab. 1, rys. 4). Dostęp do komputera, a co za tym idzie do usług internetowych w znaczący sposób wpływa na poszerzenie świadomości producentów rolnych na temat integrowanej ochrony roślin. W celu ułatwienia dostępu rolnikom do tych informacji niezbędne jest: organizowanie dla zainteresowanych spotkań informacyjnych oraz szkoleń z obsługi komputera i dostępu do narzędzi internetowych. Ponadto, nawiązanie szerszej współpracy między ośrodkami doradztwa rolniczego poprzez szkolenia doradców z zakresu omawianej tematyki.

Badani producenci rolni, poproszeni o wskazanie preferowanych form doskonalenia wiedzy $\mathrm{z}$ zakresu integrowanej ochrony roślin wymienili przede wszystkim szkolenia organizowane przez ośrodki doradztwa rolniczego $\mathrm{w}$ formie tradycyjnej - 27,8\%, jak również za pomocą fachowej prasy rolniczej, broszur doradczych, informatorów, itd. - 22,1\%. Tylko $16,1 \%$ badanych rolników wskazało na współpracę z wykwalifikowaną kadrą doradców państwowych i prywatnych. $\mathrm{Z}$ innych form doskonalenia wiedzy, które wybrali ankietowani to: wycieczki rolnicze, targi - $11,2 \%$ oraz prowadzenie dyskusji i przeglądanie stron internetowych dotyczących branży rolniczej - 10,6\%. Najmniejszym zainteresowaniem producentów rolnych cieszyły się szkolenia e-lerningowe $-3,4 \%$ oraz studia podyplomowe $-0,9 \%$.

Rolnicy poproszeni o wymienienie podstawowych źródeł, z których czerpią informacje o nowościach w rolnictwie, wskazywali przede wszystkim prasę rolniczą - 25,8\%, służby doradztwa rolniczego, w tym szkolenia organizowane przez ośrodki doradztwa rolniczego $17,5 \%$, internet - $17,3 \%$, targi $\mathrm{i}$ wystawy rolnicze, wycieczki - 16,5\%, a w mniejszym stopniu publikacje naukowe, książki czy też informacje uzyskane od innych rolników i inspektorów $(4,7 \%)$.

Wśród potrzebnych działań na rzecz wzmocnienia i upowszechnienia wiedzy w zakresie omawianych zagadnień, ankietowani zdecydowanie opowiadali się za podno- szeniem kwalifikacji doradców - 20,3\%, zwiększeniem liczby kursów i szkoleń - 20,1\%, tworzeniem specjalistycznych darmowych programów komputerowych $17,1 \%$ oraz tworzeniem specjalistycznych platform internetowych, czy portali agronomicznych - 11,8\%. Wśród rolników, ponad 30,7\% ankietowanych nie widzi potrzeby działań na rzecz upowszechnienia wiedzy z zakresu integrowanej ochrony lub nie miała na ten temat zdania.

Przygotowanie edukacyjne, umiejętności wykorzystania dostępnej wiedzy i oryginalność podejmowania decyzji to podstawowe czynniki gwarantujące efektywność innowacyjną rolników (Chyłek 2009). Z odpowiedzi ankietowanych wynika, że zainteresowanie rolników szkoleniami jest średnie, 30,0\% ankietowanych zadeklarowała, że chciałaby uczestniczyć w profesjonalnych szkoleniach organizowanych przez lokalne ośrodki doradztwa rolniczego. Większość z nich ocenia te szkolenia jako podstawowe źródło informacji o działaniach związanych $\mathrm{Z}$ integrowaną ochroną roślin. Z rozmów przeprowadzonych $\mathrm{z}$ rolnikami wynika, że wielu $\mathrm{z}$ nich wykazuje chęć do uczestnictwa w kolejnych szkoleniach, rozszerzających ich wiedzę na ten temat. Również $\mathrm{z}$ badań Kiełbasy i Krysztoforskiego (2009) przeprowadzonych wśród doradców ośrodków doradztwa rolniczego wynika, że rolnicy interesują się szkoleniami rolniczymi w średnim (55\%) lub dużym i bardzo dużym stopniu (35\%). Autorzy podają, że tylko około $10 \%$ rolników wykazuje małe zainteresowanie szkoleniami.

Podsumowując, z badań Pondel (2008) wynika, że mimo podejmowanych inicjatyw i wykonanych działań, pojęcie rolnictwa integrowanego jest obce dla przeważającej części producentów rolnych. $\mathrm{Na}$ podstawie uzyskanych odpowiedzi można wyciągnąć wniosek, iż wiedza ankietowanych na temat zagadnień związanych $\mathrm{z}$ integrowaną ochroną roślin ogranicza się do znajomości podstawowych definicji związanych $\mathrm{z}$ wejściem w życie Dyrektywy UE 2009/128/WE, odnoszącej się do prowadzenia gospodarstwa, zgodnie $\mathrm{z}$ wymogami obowiązującymi w Polsce od 1 stycznia 2014 roku. Przyczynę tego zjawiska należy upatrywać $\mathrm{w}$ braku wiedzy lub jej nieusystematyzowania.

\section{Wnioski / Conclusions}

$\mathrm{Na}$ podstawie zebranych ankiet sformułowano następujące wnioski:

1. Poziom przygotowania i wiedzy rolników z zakresu integrowanej ochrony potrzebny przy prowadzeniu gospodarstwa jest bardzo różny. Większość z producentów rolnych jest świadoma powszechnego i obowiązkowego stosowania zasad integrowanej ochrony roślin $\mathrm{w}$ prowadzeniu gospodarstwa rolnego. $\mathrm{Z}$ grupy tej około $37,8 \%$ rolników udzieliło odpowiedzi, że pierwszy raz usłyszeli o tym zagadnieniu $\mathrm{w}$ momencie wejścia w życie Dyrektywy UE.

2. Rozpatrując znajomość terminu i zasad integrowanej ochrony w oparciu o kryterium wykształcenia rolnika, należy stwierdzić, że im wyższy poziom wykształcenia tym większa znajomość omawianego zagadnienia. Stwierdzono istotne różnice między grupami rolników 
posiadających wykształcenie podstawowe i zawodowe w stosunku do rolników legitymujących się wykształceniem na poziomie średnim i wyższym, przy czym dwie ostatnie grupy nie różniły się w sposób istotny.

3. Osoby młode, częściej niż starsze wskazywały, że przedsiębiorstwo rolne powinno być prowadzone zgodnie z wytycznymi, dla zabezpieczenia zdrowej żywności i ograniczenia liczby zabiegów chemicznych szkodliwych dla środowiska. Z przeanalizowanych ankiet wynika, że wraz z wiekiem, stosowanie systemów zmniejszających ryzyko zagrożeń dla ludzi i środowiska malało. Przy czym rolnicy w wieku powyżej 60 . roku życia wraz z nabytym długoletnim doświadczeniem w prowadzeniu gospodarstwa rolnego wykazywali się większą wiedzą na temat integrowanej ochrony roślin.

4. Wykazano istotną zależność wyrażania przez rolników opinii na temat ich wiedzy z zakresu omawianych zagadnień a powierzchnią gospodarstwa, przy czym rolnicy gospodarujący większym areałem (powyżej 100 ha) wykazywali się większą znajomością metod i zagadnień związanych z integrowaną ochroną roślin.

5. Posiadanie komputera, a co za tym idzie dobra znajomość jego obsługi, jak również korzystanie z usług internetowych w znaczący sposób wpływa na poszerzenie świadomości producentów rolnych w tym zagadnieniu. Badania ankietowe wskazują, na jakie zagadnienia szkoleniowe powinni zwracać szczególną uwage pracownicy doradztwa rolniczego. Potrzebne rozpoznanie potrzeb szkoleniowych to warunek dobrej motywacji i zaangażowania rolników w proces szkolenia.

6. Konieczne jest przyspieszenie działań upowszechniających i dokształcających oraz zwiększenie dostępności doradztwa rolniczego (państwowego, jak i prywatnego) jako głównej formy przekazywania wiedzy rolnikom.

\section{Literatura / References}

Bisaga A. 2014. Rola sieci dyfuzji wiedzy i informacji w procesie modernizacji gospodarstw rolnych na przykładzie województwa opolskiego. [The role of knowledge and information diffusion network in the process of modernization of agricultural households on the basis of the Opole region]. Journal of Agribusiness and Rural Development 3 (32): 17-35.

Chyłek E. 2009. Znaczenie wiedzy we wzroście innowacyjności na obszarach wiejskich. [The meaning of knowledge in the increase of innovativeness on rural areas]. Zagadnienia Doradztwa Rolniczego 1, s. 9.

Czekaj M.B. 2013. Wykorzystanie komputerów w wybranych gospodarstwach rolnych województwa małopolskiego. [The use of computers in farms in Małopolska district]. Zagadnienia Doradztwa Rolniczego 3: 88-97.

Czernyszewicz E., Kwiatkowska K., Kopiński Ł. 2015. Aspekty środowiskowe w wymaganiach systemów jakości stosowanych w ogrodnictwie. Prace Naukowe Uniwersytetu Ekonomicznego we Wrocławiu 377: 146-158.

Czernyszewicz E., Pawlak J. 2012. Uwarunkowania i kierunki zapewnienia bezpieczeństwa i jakości owoców i warzyw. http://zif. wzr.pl/pim/2012_3_3_10.pdf [dostęp: 10.10.2013].

Golinowska M., Kruszyński M., Wiciak T., Rutkiewicz K. 2014. Zużycie środków ochrony roślin oraz koszty i opłacalność redukowania stanu zachwaszczenia w gospodarstwie indywidualnym w latach 2004-2013. [Usage of plant protection products, costs and profitability of reducing weed infestation an individual farm in the years 2004-2013]. Progress in Plant Protection 54 (4): $437-443$.

Kiełbasa B., Krysztoforski M. 2009. Potrzeby doradcze rolników w opinii pracowników Wojewódzkich Ośrodków Doradztwa Rolniczego. [The farmers advisory needs in opinion of workers of voivodoship agricultural advisory centers]. Zagadnienia Doradztwa Rolniczego 2, s. 53.

Kruszyński M., Golinowska M., Borkowska M., Wiciak T. 2015. Świadomość pro-środowiskowa producentów rolnych a stan integrowanej ochrony roślin w Polsce. [Pro-environmental awareness of agricultural producers and integrated pest management in Poland]. Progress in Plant Protection 55 (1): 114-118.

Marks N., Jakubowski T., Nawara P. 2012. Internet jako źródło pozyskiwania wiedzy potrzebnej do prowadzenia gospodarstwa rolnego. [The internet as a source of knowledge necessary for running an agricultural farm]. Agricultural Engineering/Inżynieria Rolnicza 2 (136), t. 1: 195-204.

Matyjaszczyk E., Tratwal A., Walczak F. 2010. Wybrane zagadnienia ochrony roślin w rolnictwie ekologicznym i integrowanej ochronie roślin. Instytut Ochrony Roślin - PIB, Poznań, 103 ss.

Pondel H. 2008. Metody produkcji rolnej przyjazne środowisku w opinii wielkopolskich producentów rolnych. s. 214- 219. W: „Jakość. Bezpieczeństwo. Ekologia w sektorze rolno-spożywczym. Kierunki rozwoju” (M. Wiśniewska, E. Malinowska, red.). Fundacja Rozwoju Uniwersytetu Gdańskiego, Sopot, 401 ss.

Tratwal A., Horoszkiewicz-Janka J., Bereś P.K., Walczak F., Podleśny A. 2014. Przydatność aplikacji komputerowej do wyznaczania optymalnego terminu zwalczania rdzy brunatnej pszenicy. [Fitness computer application deadline for determining optimal control of wheat rust brown]. Zagadnienia Doradztwa Rolniczego 3: 106-113.

Walczak F. 1999. Znaczenie monitoringu agrofagów roślin uprawnych dla ochrony roślin. [The importance of monitoring pests of crops for plant protection]. Progress in Plant Protection/Postępy w Ochronie Roślin 41 (2): 386-390.

Walczak F., Tratwal A., Krasiński T. 2010. Kierunki rozwoju prognozowania i sygnalizacji agrofagów w ochronie roślin rolniczych. [Directions of the development of pest forecasting and warning systems in plant protection]. Progress in Plant Protection/Postępy w Ochronie Roślin 50 (1): 81-86. 